\title{
A Note on the Amphibian Fauna at Pantai Melawi Bachok, Kelantan
}

\author{
Daicus Belabut ${ }^{1,2 *}$, Rosli Hashim ${ }^{1}$, Yong Hoi Sen ${ }^{1}$, Siti Zaleha Mat Diah ${ }^{1}$, Norhayati \\ Ahmad $^{2,3}$ and Lim Boo Liat ${ }^{4}$ \\ ${ }^{1}$ Institute of Biological Sciences, Faculty of Science, University of Malaya, 50603 Kuala Lumpur. \\ ${ }^{2}$ Institute for Environment and Development (LESTARI), Universiti Kebangsaan Malaysia, 46300 UKM Bangi, \\ Selangor Darul Ehsan. \\ ${ }^{3}$ Faculty of Science and Technology, Universiti Kebangsaan Malaysia, 43600 Bangi, Selangor Darul Ehsan. \\ ${ }^{4} 12$ Jalan Koop Cuepacs 3E, Taman Cuepacs, 43200 Cheras, Selangor. \\ *daicus@um.edu.my (corresponding author) \\ Received on $2^{\text {nd }}$ July 2009, accepted in revised form $28^{\text {th }}$ October 2009.
}

ABSTRACT Five species of amphibians were found at Melawi, Bachok, Kelantan. Kaloula pulchra, Fejervarya limnocharis and Duttaphrynus melanostictus were the predominant species. Only a single individual of Polypedates leucomystax and an exotic species Hoplobatrachus rugulosus respectively was also found here.

ABSTRAK Lima spesies amfibia dijumpai di Melawi Bachok, Kelantan. Kaloula pulchra, Fejervarya limnocharis dan Duttaphrynus melanostictus adalah spesies yang paling kerap ditemui dan masing-masing satu individu Polypedates leucomystax dan spesies eksotik Hoplobatrachus rugulosus dijumpai di kawasan ini.

(Keywords: anurans, sandy habitat, bioindicator, Kelantan.)

\section{INTRODUCTION}

Pantai Melawi Bachok, Kelantan ( $\mathrm{N} \mathrm{06}^{\circ} 00.532^{\prime}$; E $102^{\circ} 25.521^{\prime}$; a.s.1. $<10$ meters) is an area of long uninterrupted sandy beach with sparsely distributed kampong houses interspersed with coconut plantations and strips of casuarina trees along the stretch. A large proportion of these fields looked as though they were abandon or non-productive coconut grooves. The study area covered more than four hectares of rectangular shaped land bordered by beach on seaward and a narrow natural drainage (brackish) about 100 meters towards the leeward side.

The vegetation cover comprised of the tall coconut trees (Cocos nucifera), wild screw pine (Pandanus tectorius) and planted casuarina trees (Casuarina equisetifolia). The sandy ground surface is sparsely covered by several species of grasses including the cow-grass (Axonopus cf. compresses), love grass (Chrysopogon aciculatus) and other wild grasses with some bush thickets (especially along the drain). The edaphic landscape of Bachok areas is generally made up of alluvial deposit [1], while the top soil cover consists of dry humus and sand.

Herpetofaunal records of sandy coastal habitats include reptiles e.g. sea turtles $[2,3,4,5,6,7]$, sea snakes $[8,9,10,11,12]$, and lizards $[8,9]$. On the other hand, amphibian fauna records are scarcely reported from sandy habitats. This paper reports the amphibian species found at Pantai Melawi Bachok, Kelantan.

\section{MATERIALS AND METHODS}

We spent three hours (20:00 - 23:00 hours) every night for two consecutive nights (12-13 April 2009) to survey the site and its surrounding areas. The site is designated for setting up of the research station of the Institute of Oceanography and Earth Sciences Research Station (IOES) of the University of Malaya.

All the amphibian species encountered were photographed in-situ after which, they were collected and kept in plastic bags before they were brought back to be processed. Animals were anesthetised using Tricaine solution (Ethyl 3-aminobenzoate methanesulfonate salt), weighed and measured for the snout-vent length (SVL) and tibia length (TL) with a dial calliper (Mitutoyo Digimatic) to the nearest 0.1 $\mathrm{mm}$. A small piece of tissue was taken from the thigh muscle for each specimen and preserved in 99.8\% undenatured absolute alcohol for DNA analysis. Postmetamorphic specimens were then fixed in $10 \%$ formalin and transferred to $70 \%$ alcohol for storage. Nomenclatures of Berry [13], Frost [14] and van Kampen [15] were followed. All specimens were deposited at the Zoological Museum, Institute of 
Biological Sciences, University of Malaya, Kuala Lumpur.

\section{RESULTS AND DISCUSSION}

The weather was dry and windy during both nights. A total of five species of anurans were collected from the small study area at Pantai Melawi, Bachok, Kelantan. They belonged to four families Bufonidae, Dicroglossidae, Microhylidae and Rhacophoridae. All anuran species around the survey area were generalist species (species of anurans that are well adapted to disturbed habitats). They were abundant and commonly found within the

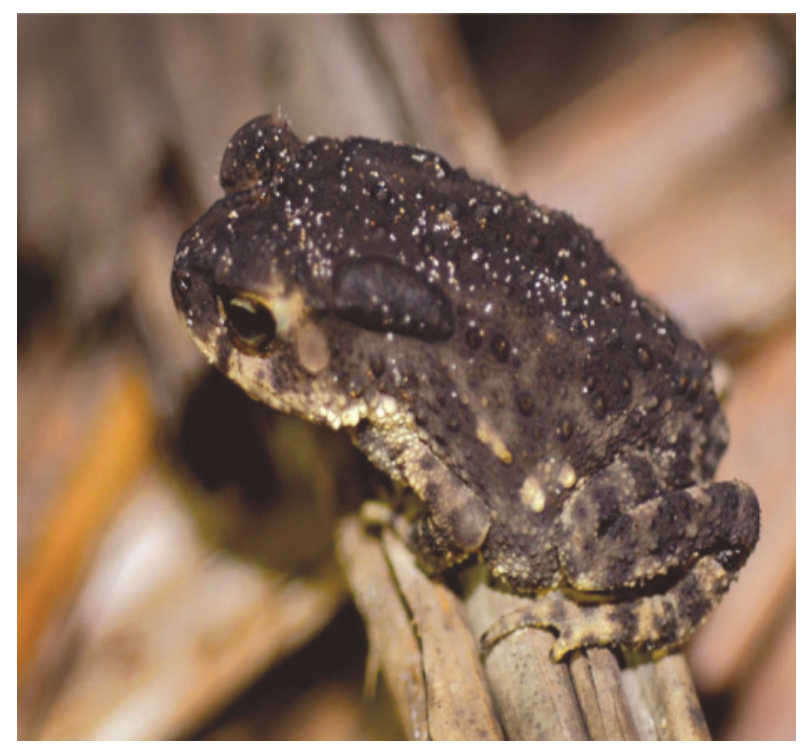

Figure 1. Dorsal-lateral view of juvenile Duttaphrynus melanostictus

Species account

Class Amphibia: Order Anura

Family Bufonidae

Duttaphrynus melanostictus (Schneider, 1799)

Common house toad / Asian black-spotted toad. Figures 1 and 2.

Remarks - Abandoned coconut plantations near brackish stream, 12 April 2009, D0251: A male human habitations and other disturbed landscapes. These are commensal species because of their ability to survive the threats to which other sensitive species have succumbed [16]. All are associated with altered or disturbed habitats.

A single specimen of an exotic species of Hoplobatrachus rugulosus was also found. This species is being reared in frog farms e.g. $\mathrm{Kg} \mathrm{Jambu}$ in Tumpat, Kelantan (ca. $40 \mathrm{~km}$ from Bachok). Without proper surveillance and control, this introduced species could establish itself and replace native species in this country, due to their ferocious feeding habits.

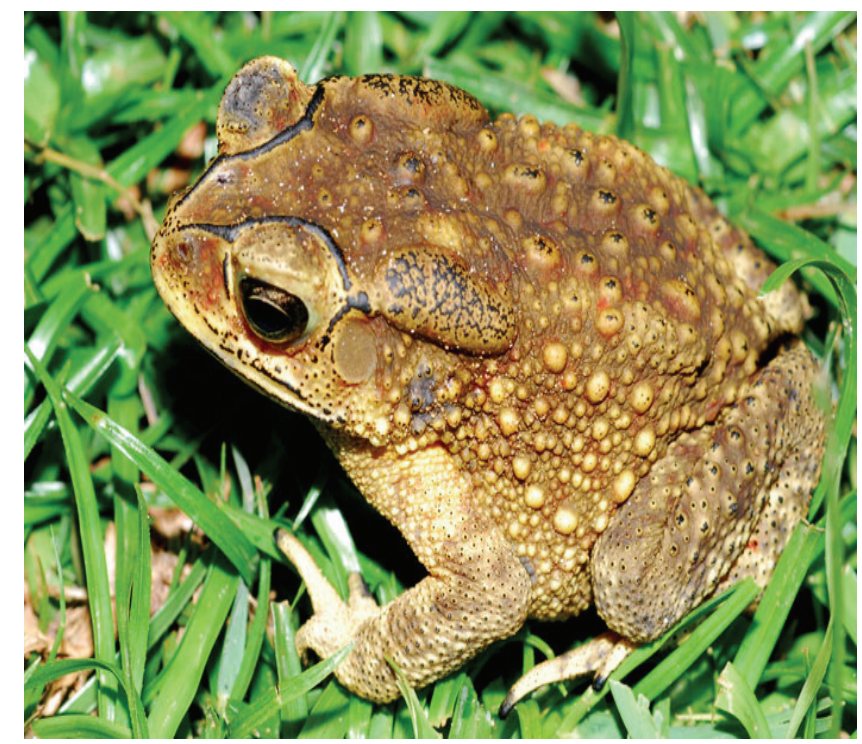

Figure 2. Dorsal-lateral view of adult Duttaphrynus melanostictus

juvenile (SVL - 35.6mm) perching on dead coconut leaf just next to brackish water stream was collected and photographed. Several adult males and females were encountered during our survey around the area. They were photographed to show colour variation. At night the juveniles were mainly black in colour and the adults with brown or yellowish brown above, sometimes with carmine-coloured spots. They were commonly found on grass, bare soil and dry coconut leaves. 


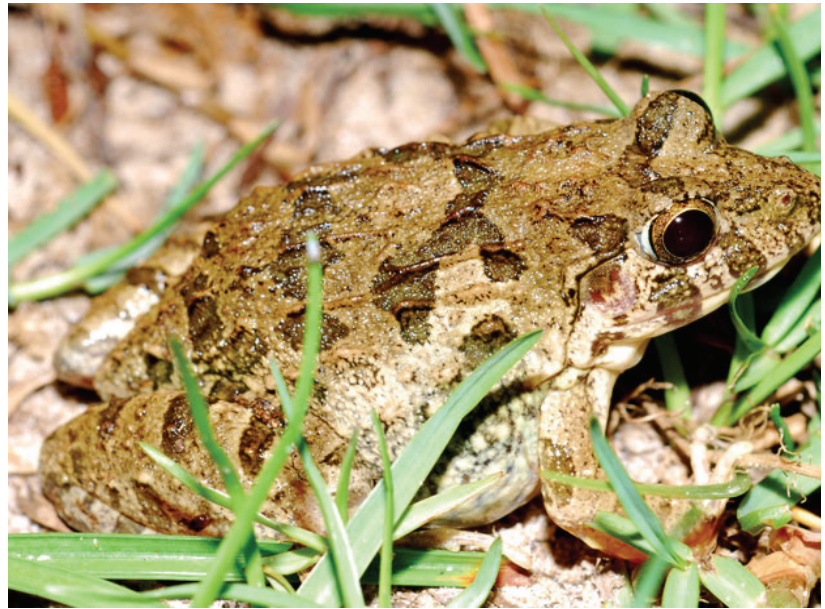

Figure 3. Dorsal-lateral view Fejervarya limnocharis without vertebral line

Family Dicroglossidae

Fejervarya limnocharis (Gravenhorst, 1829)

Paddyfield frog / Cricket frog

Figures 3 and 4 .

Remarks - Brackish stream edges, 12 - 13 April 2009, D0250, D00252, 0253, 0254: Three females (SVL $-69.61 \mathrm{~mm}, 71.27 \mathrm{~mm}$, and $76.64 \mathrm{~mm}$ ) and one

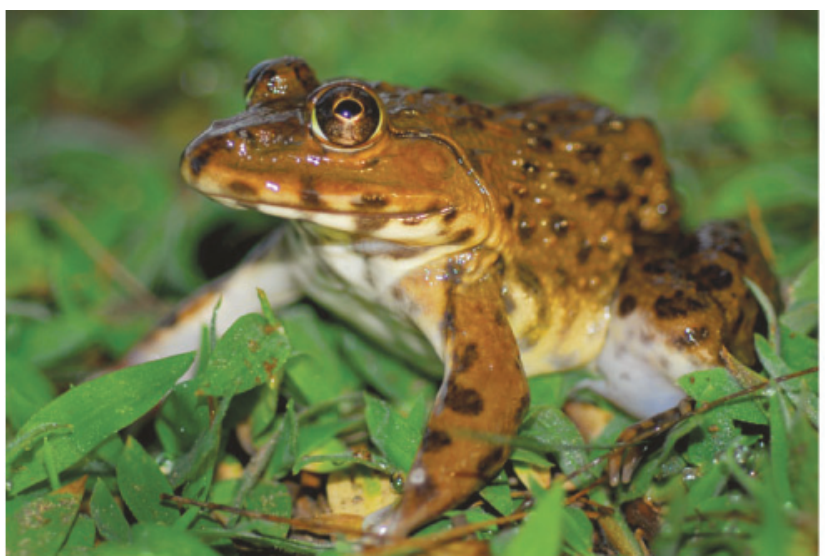

Figure 5. Anterior-lateral view of Hoplobatrachus rugulosus

Family Dicroglossidae

Hoplobatrachus rugulosus (Wiegmann, 1834)

Taiwanese frog / Chinese bullfrog

Figures 5 and 6.

Remarks - At the water edge along the brackish stream, 12 April 2009, D0248: A single individual male (SVL - 93.18mm) was found at the edge of the stream just a meter away from the small wooden

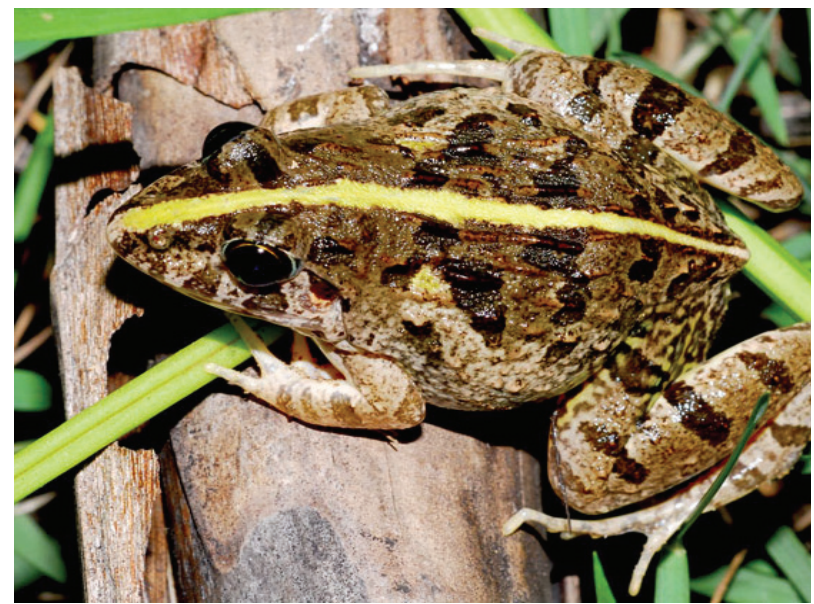

Figure 4. Dorsal-lateral view Fejervarya limnocharis with vertebral line

male (SVL $-41.62 \mathrm{~mm}$ ) were collected about 1 to 2 meters away from the brackish water stream edges. They are commonly found in disturbed habitats or near to human habitations. Dorsum skin with narrow longitudinal ridges. At night, their upper surface colours were light brown or olive brown with darker spots. Two morphs occurred in this area, with- and without vertebral line.

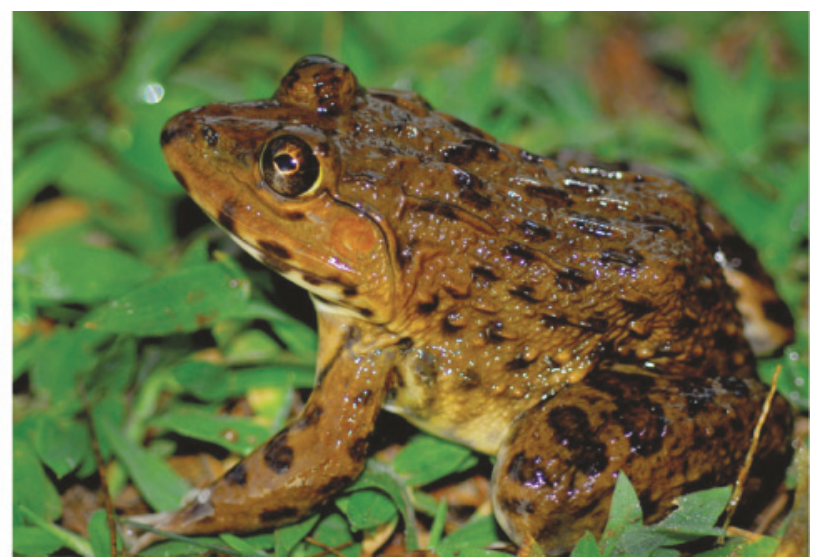

Figure 6. Dorsal-lateral view of Hoplobtrachus rugulosus

bridge. This species is not native to Peninsular Malaysia. It was introduced to this country for food and due to high demands for their meaty legs; they are being farmed at various places throughout Peninsular Malaysia. Some of the individuals are escapees and are able to adapt to local habitats. Live specimens had been collected on two occasions along the old trunk road in Gombak, Selangor (Daicus Belabut, personal observation). 


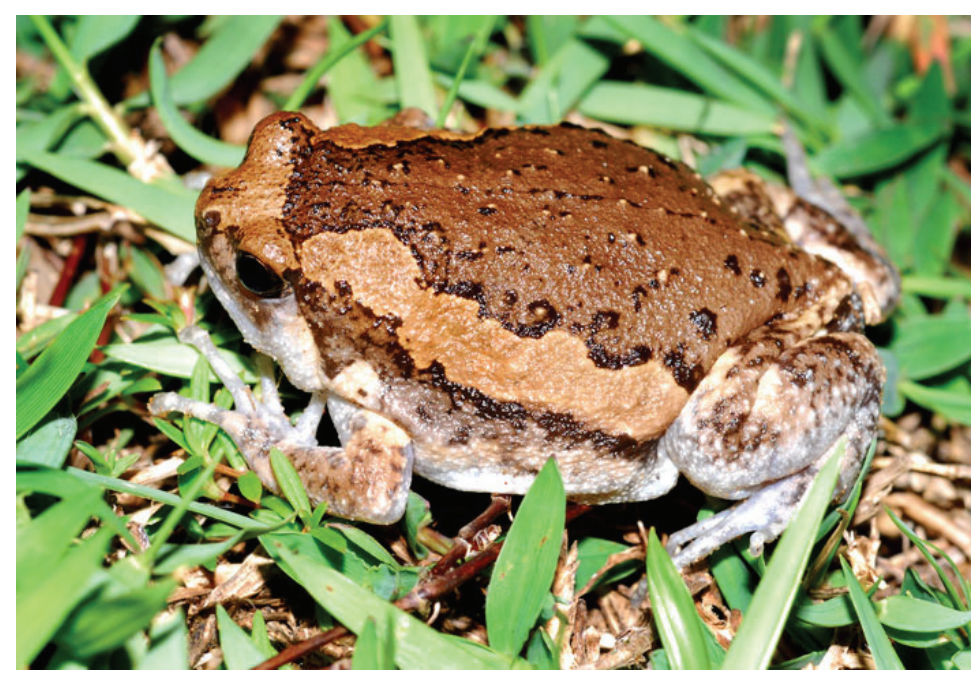

Figure 7. Dorsal-lateral view of Kaloula pulchra

Family Microhylidae

\section{Kaloula pulchra Gray, 1831}

Malaysian bullfrog / Painted burrowing frog Figure 7.

Remarks - On sandy soil and grasses around the designated IOES Research Station, 12 - 13 April
2009, D0249: An individual male (SVL - 44.26mm) was found resting on cow-grasses and collected. Several adults were spotted but no advertisement call was heard during the night survey. This was probably due to the dry season. This species is one of the most common frogs that we encountered. In addition to the study site, this frog was also encountered in the chalets at Pantai Irama.

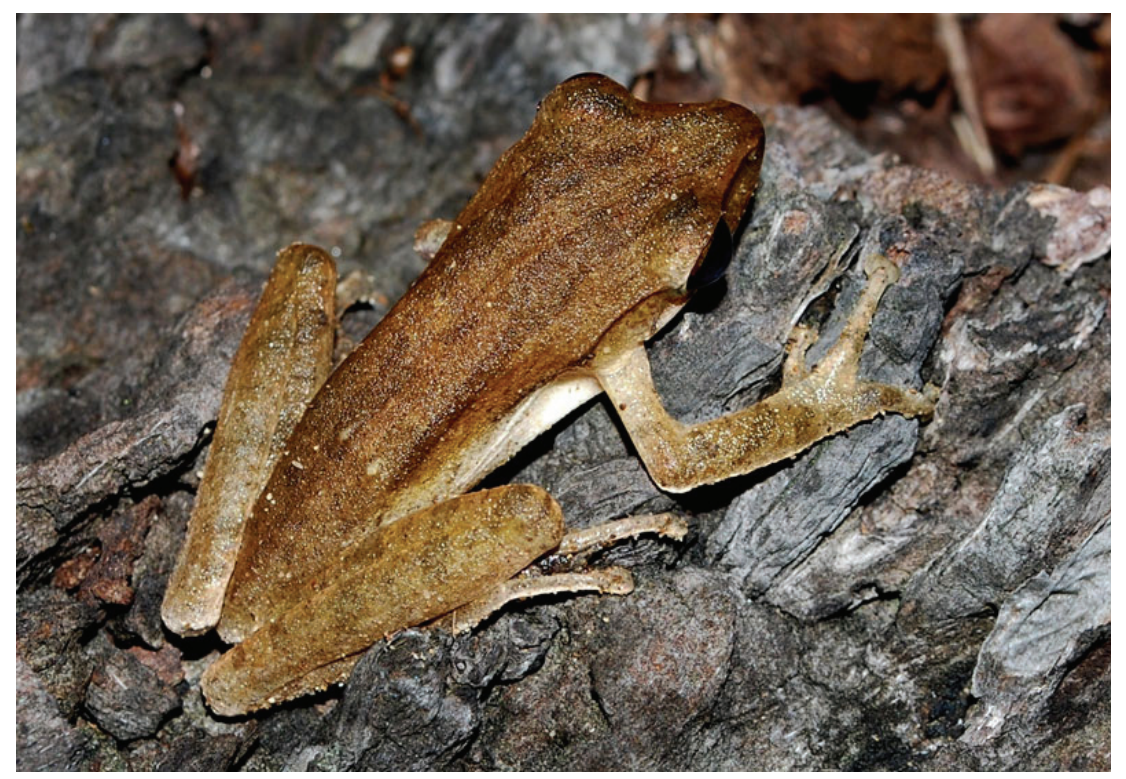

Figure 8. Dorsal-lateral view of Polypedates leucomystax (photo H.S. Yong)

Family Rhacophoridae

Polypedates leucomystax (Gravnernhost, 1829)

Four-lined treefrog / Common treefrog

Figure 8.
Remarks - On dead coconut trunk at the dry sandy shore, 12 April 2009, D0247: An adult male (SVL $41.85 \mathrm{~mm}$ ) with four-lined stripes on dorsum perching on a fallen dead coconut trunk. 


\section{CONCLUSIONS}

The number of anuran species found in this study area is very low. All of them are generalist species and commonly found at altered habitats. In order to understand the occurrence of anurans within sandy habitats, a prolonged sampling programme is essential.

\section{ACKNOWLEDGEMENTS}

This research was funded by PJP Agihan 12008 (FS295/2008A) of Universiti Malaya.

\section{REFERENCES}

1. Abd. Rahim Samsudin, Umar Hamzah, Abd. Ghani Rafek and Haryono. 1996. Results on Geophysical Survey of Areas in Bachok, Kelantan). Sains Malaysiana, 25 (1): 29 - 43

2. Balasingam, E. 1965. Turtle Conservation Results of 1965 Hatchery Programme. Malayan Nature Journal 20: 139 - 141

3. Balasingam, E. 1965a. The Giant Leathery Turtle Conservation Programme, 1964. Malayan Nature Journal 19: 145 - 146

4. Balasingam, E. 1965b. Conservation of Green Turtle (Chelonia mydas) in Malaya. Malayan Nature Journal 19: 235 - 236

5. Kiew, B.H. 1984. Conservation Status of the Malaysian fauna. IV. Turtles, Terrains and Tortoises. Malaysian Naturalist 38 (2): 2- 3

6. Chan, E.H. and Liew, H.C. 1989. The Leatherback Turtle. A Malaysian Heritage. Tropical Press Sdn. Bhd. Kuala Lumpur. pp. 49

7. Liew, H.C., Can, E.H., Papi, F. and Litschi, P. 1996. Long distance Migration of Green Turtles from Redang Island, Malaysia: The need for Regional Cooperation in Sea Turtle Conservation. Devaux, B (ed.). pp. 73 - 75. In: Proceeding of the International Congress of Chelonian Conservation. Editions Soptom, Gonfron.

8. Chan-Ard, T., Grossmann, W., Gumprecht, A. and Schultz, K. 1999. Amphibians and Reptiles of Peninsular Malaysia and Thailand, Bushmaster Publications. Wuerselen, Germany. pp. 240

9. Cox M.J., van Dijk P.P., Nabhitabhata J. and Thirakhupt K. 1998. A photographic guide to snakes and other reptiles of Peninsular Malaysia, Singapore and Thailand. New Holland Publishers (UK) Ltd. pp. 144

10. Lim, B.L. 1982. Poisonous Snakes of Peninsular Malaysia. 2nd Ed. Malayan Nature Society, Kuala Lumpur. pp. 73
11. Smith, M.A. 1930. The Reptilia and Amphibia of Malay Peninsula. Bulletin Raffles Museum, 3: 1 $-130$

12. Tweedie, M.W.F. 1957. The Snake of Malaya. Government Printing Office, Singapore. pp. 143

13. Berry, P.Y. 1975. The Amphibian Fauna of Peninsular Malaysia. Tropical Press, Kuala Lumpur. pp. 130

14. Frost, D.R. 2009. Amphibian Species of the World: an Online Reference. Version 5.3 (12 February, 2009). Electronic Database accessible thttp://research.amnh.org/herpetology/amphibia/ American Museum of Natural History, New York, USA.

15. Van Kampen, P.N. 1923. The Amphibian of Indo-Australian Archipelago. E.J.Brill Ltd., Leiden (Holland). pp. 304

16. Kiew, B.H. 1997. Frogs and toads. In The Encyclopedia Malaysia: Animal. pp. 74 - 75. Yong, H.S. (Ed). Didier Millet Pte Ltd, Archipelago Press. 